\title{
LibGuide som social platform
}

\section{Af Susanne Nielsen, Berit Volder Kjær og Bente Thorup Andersen}

\begin{abstract}
Artiklens formål er at belyse udviklingsprojektet omkring udformningen af e-loeringsvorktøjet LibGuide. LibGuide er planlagt som en digital og didaktisk vorktøjskasse, der skal understøtte informationskompetence i gymnasierne. Undervisere og bibliotekarer skal sammen ved brug af vorktøjet udarbejde undervisningsforløb. Det er formålet herved at højne både kvaliteten af undervisningen og udviklingen af elevernes informationskompetence. LibGuide er planlagt til at skulle understøtte en kommunikativ forståelse og samarbejdet mellem eleverne og bibliotekar/ laerer, dvs. der er fokus på det sociale aspekt. Artiklen viser at de ncevnte mål indeborer et eksplorativt udviklingsforløb. Udviklingen af et vaerktøj, der skal indfri de noevnte samarbejdsmoessige aspekter, forudscetter en evalueringsproces, hvor der gives tid til erhvervelsen af mange erfaringer og refleksioner. Artiklen gør rede for de ideer, der ligger bag udviklingen af prototypen i fase 1 samt hvilket indhold denne forste prototype havde. Dernoest beskrives fase 2, hvorledes prototypen er anvendt i undervisningen,
\end{abstract}

Susanne Nielsen, Master i Biblioteks- og Informationsvidenskab; Videnmedarbejder/bibliotekar på Erhvervsakademi MidtVest (sni@eamv.dk) Berit Volder Kjar, Bibliotekar DB; Bibliotekar på Struer bibliotek(bvk@struer.dk)

Bente Thorup Andersen, Cand.scient.bibl; Bibliotekar på University College Nordjylland, Teknologi \& Business (bta@ucn.dk) hvordan den blev evalueret og herunder hvilke resultater der kom ud af dette. I artiklens sidste del gennemgås fase 3, nemlig kravspecifikationen, der bygger på de ncevnte resultater samt øvrige erfaringer. Afslutningsvis reflekteres der over projektets forløb.

\section{Indledning}

Artiklens formål er at belyse udviklingsprojektet omkring udformningen af e-læringsværktøjet LibGuide. LibGuide er planlagt til at blive en digital og didaktisk værktøjskasse, der skal understøtte informationskompetence i gymnasierne.

Der sidder mange dygtige og engagerede uddannelsesbibliotekarer rundt omkring på de danske gymnasiale uddannelser. Mange af disse bibliotekarer underviser gymnasieeleverne i informationssøgning og har hver deres tilgang og metoder til dette. På nogle gymnasier samarbejder bibliotekaren tæt med skolens undervisere i forbindelse med denne undervisning, men andre steder står bibliotekaren alene med denne opgave. Det var disse erfaringer, der satte gang i projekt LibGuide og udviklingen af en prototype, som havde til formål først og fremmest at skulle bruges til at videndele undervisningsmateriale og udvikle samarbejdet mellem bibliotekar og underviser for at fremme kvaliteten af undervisningen $\mathrm{i}$ informationskompetence.

LibGuide er planlagt til for det første at være et værktøj, der kan hjælpe med at få informationssøgning ind i alle fag på ungdomsuddannelserne. Den 
skal kunne bruges efter behov og i den aktuelle kontekst. For det andet skal den være et værktøj, der opfordrer til en kommunikativ forståelse, og hvor samarbejdet mellem eleverne, samt elever og bibliotekar/lærer, er af stor betydning. "Det bliver tydeligt, hvordan informationskilder får mening i dialogen mellem aktørerne inden for en social praksis. Dette fremgår af vejledningerne, når det f.eks. diskuteres, hvordan informationens validitet skabes.." (Sundin, 2006, s. 89). Det samarbejdsmæssige aspekt er således en særdeles central intention.

For det tredje er det et mål, at elevernes fantasi og kombinationsevne skal stimuleres, og dette mener vi kan ske via en e-læringsplatform, som får eleverne til at synes, at det er spændende at arbejde med informationssøgning. LibGuide skal indeholde en værktøjskasse med undervisningsmoduler, som man frit kan plukke af og sammensætte efter behov. Der skal også være mulighed for, helt fra bunden, at udforme og udvikle egne moduler til præcis det aktuelle projekt, som eleverne arbejder med. Det skal være en platform, der, som slutprodukt, skal kunne bruges på de gymnasiale uddannelser og give underviserne et redskab til at forbedre elevernes studiekompetencer og hermed optimere de unges sans for at opsøge viden, jvf. Bekendtgørelse af lov om uddannelse til studentereksamen, § 2, stk. 3: "Eleverne skal gennem uddannelsens faglige og pædagogiske progression udvikle faglig indsigt og studiekompetence. De skal opnå en fortrolighed med at anvende forskellige arbejdsformer og evne til at fungere i et studiemiljø, hvor kravene til selvstændighed, samarbejde og sans for at opsøge viden er centrale".

I denne artikel vil vi præsentere det udviklingsarbejde, der hidtil er foregået omkring LibGuide og herved forsøge at begrunde relevansen af en videreførelse af LibGuide-projektet. Indledningsvis kommer vi ind på to teoretiske inspirationskilder for projektet, nemlig dels begrebet om en kommunikationsorienteret webvejledning i informationskompetence og dels begrebet om 'digital natives'. Dernæst beskriver vi projektgruppens sammensætning samt vores definition af begrebet informationskompetence. Artiklen gør herefter rede for de tanker, der ligger bag udvikling af prototypen i fase 1 samt hvilket indhold denne første prototype havde. Dernæst beskrives fase 2, nemlig hvorledes denne prototype er anvendt i undervisningen, evalueringsarbejdet, der er udført, samt hvilke resultater der er kommet ud af dette. I ar- tiklens sidste del gennemgås fase 3, nemlig kravspecifikationen, der bygger på de indsamlede resultater samt efterfølgende erfaringsopsamling. I artiklen trækker vi to andre eksisterende e-læringsplatforme frem, som også har med informationssøgning at gøre, og som har tjent som inspiration for LibGuide. Afslutningsvis reflekteres der over projektets forløb.

\section{To teoretiske inspirationskilder}

Udviklingsprojektet har to centrale teoretiske inspirationskilder. Den første handler om en kommunikationsorienteret approach til webvejledninger i informationskompetence. Den anden handler om begrebskonstruktionen 'digital natives'.

\section{Den kommunikationsorienterede webbaserede vej- ledning}

Olof Sundin har undersøgt 31 nordiske webbaserede vejledninger i informationskompetence og finder fire typer af tilgange hertil, en kilde-, en adfærds-, en proces- og en kommunikationsorienteret approach. Han skriver "En udfordring for fremtidige udviklere af vejledninger i informationskompetence - som for internetbaserede bibliotekstjenester i øvrigt - er derfor, hvordan man kan skabe en kontekstuel fleksibilitet" (Sundin, 2006, s. 91). Den kommunikationsorienterede er sammen med den kildeorienterede tilgang kontekstafhængig, dvs. indholdet afstemmes efter konteksten. Den kommunikative er derudover brugerorienteret og ikke opbygget på baggrund af f.eks. informationstype. Han finder desuden, at kun meget få webvejledninger har en kommunikativ orienteret forståelse, de fleste har enten en procesorienteret eller en adfærdsorienteret forståelse.

At arbejde med den kommunikative forståelse er lige præcis, hvad formålet med LibGuide er. Det er intentionen at den skal være en frit tilgængelig værktøjskasse, som kan fyldes med undervisningsmoduler af lærer og bibliotekar i fællesskab med det formål, at eleverne lærer i samarbejde og med dialog i fokus.

Sundin siger endvidere i sin artikel om den kommunikationsorienterede approach at "Forståelsen sætter med andre ord spørgsmålstegn ved informationssøgning som en individuel, rationel og systematisk proces, hvor søgningen har samme form uanset disciplin og kontekst. Fokus flyttes i denne forståelse fra både informationen og den enkelte bruger til brugernes deltagelse i forskellige typer af social praksis..." 
(Sundin O., 2006, s. 89). Det er en forståelse af informationssøgning som en del af en social praksis, som LibGuide skal bygge på. Det er vores opfattelse at en sådan forståelse er i overensstemmelse med en intention om at udvikle et web 2.0 platform. Begrebet web 2.0 baserer vi på den definition, som den britiske Joint Information Systems Committee (JISC) giver: "Web 2.0 refers to innovative online tools designed to enhance communication and collaboration. These include social networking sites, blogs, wikis and user-generated taxonomies or 'folksonomies'. While potential benefits continue to emerge, Web 2.0 is already providing users with greater flexibility and access to information" (http://www.jisc.ac.uk/whatwedo/topics/web2).

\section{Digital natives}

Målgruppen for LibGuide er de såkaldt 'Digital Natives', dvs. generationen, der så at sige er født ind i den digitale verden, og ikke først har skullet tilegne sig digitale færdigheder senere i livet - i modsætning til mange af underviserne og bibliotekarene, der er 'Digital Immigrants'. Disse begreber introduceredes af Marc Prensky (2001) i artiklen "Digital Natives, Digital Immigrants", hvor han karakteriserer de unge således: "Digital Natives are used to receiving information really fast. They like to parallel process and multi-task. They prefer their graphics before their text rather than the opposite. They prefer random access (like hypertext). They function best when networked. They thrive on instant gratification and frequent rewards. They prefer games to "serious" work" (Prensky, 2001, s. 2).

Prensky peger derfor bl.a. på følgende måder at tilpasse undervisningen på, så den passer bedre til de unge: Man kan anvende elementer fra computerspil, som de fleste unge er fuldkommen fortrolige med, gerne konkurrenceelementer og 'præmier'. Det skal gå hurtigt, mindre step-by-step, mere parallel-læring og multitasking. Ingen 5-10 minutter lange forløb og opgaveformuleringer, helst kun 30 sekunder (Prensky, 2001).

Vi er klar over, at ikke alle unge er, som Prensky beskriver, og at der er store forskelle inden for generationen af 'digital natives', bl.a. på grund af sociale og kulturelle faktorer. Disse og andre kritikpunkter opsummeres i artiklen The 'digital natives' debate: A critical review of the evidence (Bennet et al., 2008).
Flere forfattere peger iflg. Thomas Ryberg på, at selvom de unge er teknologivante, er det ikke ensbetydende med, at de har lige gode mediekompetencer. Mange unge er konsumerende og ikke producerende i forhold til medier, og med hensyn til informationskompetencer er mange meget lidt medierefleksive og kritiske (Ryberg, 2009).

Også Palfrey \& Gasser (2008) peger i bogen "Born Digital" på de digitale indfødtes manglende informationskompetencer og på bibliotekarens rolle som guide. "At a fundamental level, the services provided by the library ought to adjust to the way that Digital Natives are accessing information. There's never been a greater need for reference librarians that there is today, when Digital Natives are relying so heavily on Google, Wikipedia, and the places to which those sites point them" (Palfrey \& Gasser, 2008, s. 252).

'Digital natives' er en konstruktion og som sådan kan den alene tjene som en inspirationskilde. Det er vores antagelse at de unge gerne vil lære via sociale medier, i fællesskab med andre, og det vil LibGuide gerne understøtte og opmuntre til, samtidig med at elevernes informationskompetence udvikles. Det nævnte kan ses som en central vision for værktøjet LibGuide og dermed en ledetråd i udviklingsarbejdet.

\section{Projektgruppen}

Som før nævnt er det vigtigt, at bibliotekar og lærer samarbejder om den opgave det er at få unge mennesker til at blive mere informationskompetente. Dette afspejles i sammensætningen af LibGuideprojektgruppen, med repræsentanter fra både lærer- og bibliotekarside på de forskellige gymnasiale retninger, og fra gymnasiernes aftagerinstitutioner, de mellemlange og lange videregående uddannelser repræsenteret af Aalborg Universitet, UC Sydjylland og UC Nordjylland. Denne sammensætning, som har været gældende siden projektets fase 1, giver en øget viden om brugergruppen på tværs af de gymnasiale uddannelser og på tværs af fag. De tre faser er blevet finansieret af Deffs (Danmarks Elektroniske Fag- og Forskningsbibliotek) Programgruppe 'Nye institutioner' (www.deff.dk).

Ud fra en erkendelse af at de unge i målgruppen er teknologivante og stiller store krav til de teknologier, som skolerne stiller til rådighed, har der været 
fokus på at få andre unge involveret i projektets fase 3 , projektmodningen. Valget er faldet på en projektgruppe fra Aalborg Universitet (AAU), bestående af fire studerende som skriver bachelorprojekt i Informationsteknologi og Informationsvidenskab med IT-produktdesign som tema. Med inddragelse af projektgruppen fra AAU forsøger vi at sikre, at LibGuide opleves som attraktiv for målgruppen, let at bruge og designmæssigt i overensstemmelse med målgruppens æstetik.

\section{Informationskompetence}

Når vi tænker Informationskompetence, tænker vi på det at søge, kritisk vurdere og anvende information for at løse et problem. American Library Association (ALA) definerer informationskompetence på denne måde: "Information literacy is a set of abilities requiring individuals to recognize when information is needed and have the ability to locate, evaluate, and use effectively the needed information" (American Library Association (ALA), 1989).

Informationskompetence er, ifølge ALA, evnen til at finde ud af, hvornår man har et informationsbehov og derefter skaffe sig viden om, hvordan behovet kan opfyldes, hvor fokus er på en dynamisk proces. Informationskompetence drejer sig også om at lære søgeteknikker, men det afgørende er at reflektere og forholde sig kritisk til de informationer, man finder. At være informationskompetent er også evnen til at reflektere over sin viden og læring i forhold til de krav og udfordringer, der er fra omverdenen og sætte det ind i den kontekst, som er de unges hverdag.

Vi tænker ALA definitionen ind i forhold til arbejdet med LibGuide, men holder den op mod det sociokulturelle perspektiv med fokus på kommunikation i sociale praksisser. LibGuide skal fremme forståelsen mellem bibliotekaren og eleverne, hvor begge lærer af hinanden. Dette rum til forståelse gælder også bibliotekar og lærer. Dialogen mellem bibliotekarerne og faglærerne er befordrende for at forstå nuanceforskellene mellem fagene og deres orientering og for at få kendskab til hinandens fagområder. At fagunderviserne får et mere informationsfagligt kendskab er også befordrende for deres videreformidling af dette til eleverne. Eleverne skal have omformuleret deres faktuelle viden til et problembaseret spørgsmål (Limberg, Alexandersson, \& Lantz-Andersson, 2008, s. 83; Nielsen, 2010).

\section{Projektets fase 1}

Projektets hovedformål er udvikling af LibGuide som en national e-læringsplatform til undervisning $\mathrm{i}$ informationssøgning på gymnasierne. Projektgruppen vurderede at der inden for de gymnasiale ungdomsuddannelser, stx (det almene gymnasium), hhx (handelsgymnasium) og htx (teknisk gymnasium) er et behov for et e-læringsprogram, der har fællestræk med både $\mathrm{SWIM}^{1}$ og UB-testen ${ }^{2}$, men målrettet gymnasieelever.

SWIM er en e-læringsplatform, som er målrettet universitetsstuderende med fokus på, hvordan man griber projektarbejdets forskellige faser an. UB-testen er ligeledes målrettet universitetsstuderende, men går mere i dybden med selve informationssøgningsstrategien, som f.eks. hvilke databaser og opslagsværker, man skal anvende til at finde en bestemt slags information.

Indholdet i både SWIM og UB-testen er statisk, hvorimod LibGuides indhold er dynamisk og brugergeneret med mulighed for at forme det efter et hvilket som helst emne, som et givent projekt måtte have. Gymnasieeleverne skal kunne bruge LibGuide til at lære at finde informationer til et helt bestemt projekt, de måtte være i gang med; dette formodes at motivere elevernes interesse for at anvende LibGuide.

I Dalsgaard (2011) siges det at e-læringsressourcer behøver at være 'åbne' for at understøtte læring hvilket skal forstås på den måde at de ikke på forhånd har defineret bestemte problemer eller aktiviteter, som deltagerne skal i gang med. "Læringsressourcer skal stille åbne ressourcer til rådighed for individers forskelligartede aktiviteter" (Dalsgaard 2001, s.176). Det er således brugerne og ikke elæringsværktøjet, der definerer og styrer læreprocessen. Det er ikke e-læringsværktøjet der skal definere indhold eller hvordan indholdet skal anvendes, men derimod brugerne. Hverken SWIM eller UB-testen kan på denne måde kaldes en åben ressource. Det er derimod en type åben ressource, vi gerne ser udviklet med LibGuide.

For at udvikle elevernes informationskompetence skal informationssøgning integreres i såvel den faglige undervisning som i udviklingen af elevernes almene studiekompetence. Informationssøgning, kil- 
dekritik m.m. skal med andre ord ind i undervisningen i de forskellige fag. Med LibGuide har vi ønsket at skabe en platform, der udvikler informationskompetence som en del af de øvrige fags undervisning. Dette nævnte underbygges af flere biblioteksfaglige undersøgelser, hvor der er tænkt både på det empiriske, det læringsteoretiske og det organisatoriske aspekt.

Her kan henvises til for det første DEFF-rapporten "Fra information til læring", hvor Mai Aggerbeck skriver: "Sammenfattende vil min anbefaling for fremtidens biblioteksfunktion være, at funktionen folder sig ind i uddannelserne for efterfølgende at udfolde sig i praksisfællesskab. Det vil for informationskompetencen betyde at begrebet får sit indhold og sit udtryk lokalt" (Aggerbeck, 2007, s.72). For det andet konkluderer i en anden tekst Melissa Just og Hans Elbeshausen, nemlig i en artikel om gymnasiebibliotekarer, at "Anvender man i stedet for lærer betegnelsen vejleder og fokuserer man på læring som en proces, der styres af eleverne og vejlederne i fællesskab, så kunne der skabes en platform, hvor forskellige fagligheder mødes" (Just og Elbeshausen, 2008, s. 31).

En del af formålet har netop som nævnt været at fokusere på det sociale aspekt i form af samarbejdet mellem elever, undervisere og bibliotekarer og dermed ikke udelukkende på det materialeopbevarende aspekt.

Projektet har været inddelt i faser, hvor fase 1 var udarbejdelse af prototypen af LibGuide og testning af platformen i undervisningen. Platformens hjemmeside www.lib-guide.dk fungerer stadig og bliver brugt indtil den afløses af "Den nye LibGuide" (www. libguide.dk/new/). Fase 1 kørte fra februar 2008 til december 2008 og kan betegnes som en afklaringsprojektfase. I figur 1 og 2 gengives skærmbilleder fra prototypen.

Projektets fase 1 har vist, at det teknisk set er muligt at opbygge en Web 2.0 platform, hvortil alle aktører kan bidrage, og de enkelte bidrag kan genbruges og videreudvikles af andre undervisere. LibGuide bygger på et koncept, hvor integreringen af vejledning $\mathrm{i}$ informationssøgning i selve fagundervisningen er medtænkt (Nielsen, 2009a).

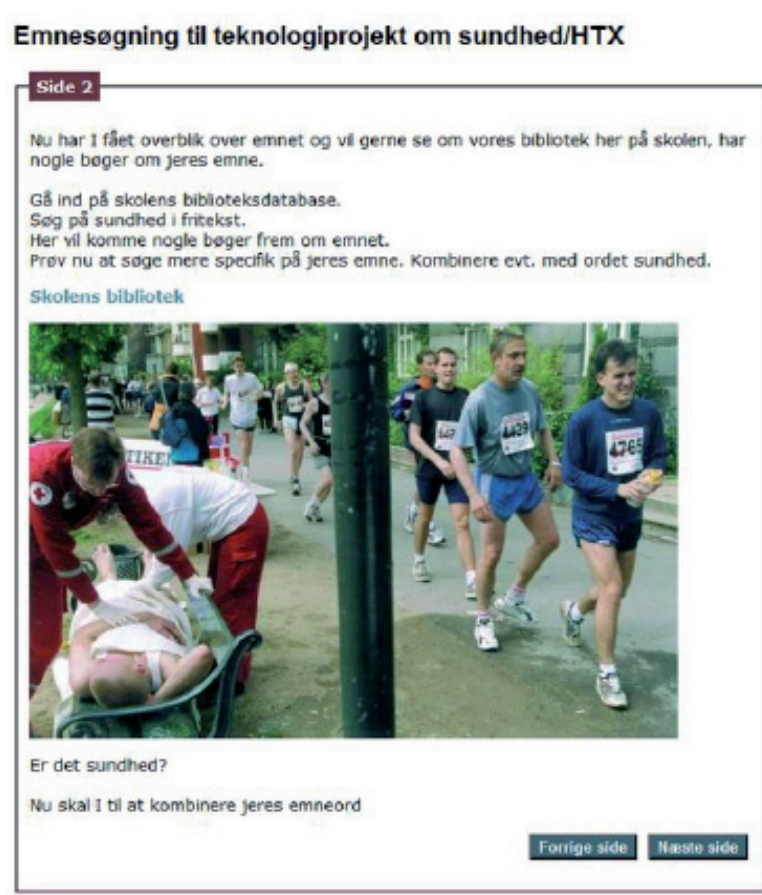

Figur 1. Skcermbillede af funktioner i prototypen www.lib-guide.dk

Forløbet må offentliggøres under Eksempler: Ja

\section{Rediger Forlabs oplysninger}

Rediger Overskritt Slet Overskrift Flyt Op Flyt Rled

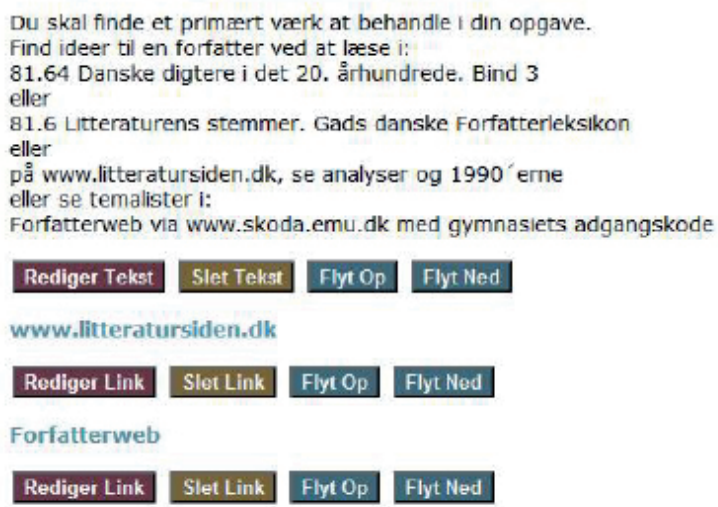

Figur 2. Skcermbillede af redigering af undervisningsforløb i prototypen www.lib-guide.dk

\section{Projektets fase 2}

\section{Forløb}

Formålet med fase 2 har været at foretage en behovsanalyse og ud fra den igangsætte fase 3 med udarbejdelsen af en kravspecifikation. Fase 2, der bestod af prototypens anvendelse i undervisningen, evaluerin- 
gen af prototypen og resultaterne heraf, gennemgås i det følgende. Fase 2 startede feb. 2010 og blev afrapporteret i november 2010.

Der er blevet undervist et stort antal elever fra både stx, htx og hhx i informationssøgning vha. LibGuide. I første uge, hvor prototypen blev afprøvet, var 180 htx elever igennem et undervisningsforløb og afsluttede med en mundtlig evaluering på klasserne (Nielsen, 2009a). I løbet af 2009 undervistes en årgang fra hver af de tre gymnasiale retninger, ialt ca. 450 elever. Der anvendtes enten mundtlig eller skriftlig evaluering (Andersen \& Nielsen, 2009; Nielsen, 2010). Der er siden undervist mindst lige så mange elever på tværs af retningerne. Der er lavet evalueringer vha. af spørgeskemaer, og der er udarbejdet lærerinterviews. Vi har brugt både lærernes og elevernes evaluering af LibGuide (prototypen) til behovsundersøgelsen (Andersen \& Nielsen, 2009; Nielsen, 2009c; Nielsen, 2010).

\section{Nogle evalueringsresultater - set fra elevside}

Prototypen af LibGuide har en del mangler med hensyn til design og funktionalitet. Men ud fra elevernes evalueringer ønskede de faktisk ikke et "fancy" design. De syntes, det var rart, at designet var minimalistisk, da det virkede nemt at bruge og samtidigt mere seriøst (Nielsen, 2009a).

Eleverne syntes, det var godt at arbejde på en anden måde vha. e-læring og mente også, at det var en god måde at lære på, hvor de syntes, de fik noget ud af det. Som LibGuide ser ud nu, finder eleverne det dog ikke relevant at bruge det samme forløb i LibGuide igen og heller ikke i andre kontekster.

Med hensyn til de indlagte tests i LibGuide havde eleverne et berettiget ønske om at få at vide, hvorfor deres svar var rigtige eller forkerte, og evt. også en forklaring på delvis rigtige svar. En high-score liste havde også høj prioritet, da de gerne ville konkurrere med hinanden.

\section{Evalueringsresultater - set fra underviser-/bibliote- karside}

I forbindelse med LibGuide projektets 2. fase er der afholdt fokusgruppeinterviews på både htx, hhx og stx, hvor deltagerne har været tre lærere fra hver gymnasieretning og med et bredt spekter af fag (Nielsen, 2010). Et af de resultater, der kom frem af interviewene, var at der synes at være bred enighed om at et netbaseret produkt giver mulighed for at ramme eleverne, når de har behov for at søge information og giver desuden variation i undervisningen (Nielsen, 2010).

Andre forslag fra fokusgruppen er følgende:

LibGuide skal bruges direkte i undervisningen. En kombination af teori og praksis anser flere af underviserne er hensigtsmæssig og pædagogisk. Det sidste fremhæves som en styrke ved programmet. Underviserne synes, at LibGuide giver afveksling og variation i undervisningen og de føler, at det giver mere tid til at gå rundt til eleverne.

Materialer, test og undervisningsforløb skal såvel fagfagligt som didaktisk være i orden, men samtidig skal alle materialetyper være velegnede til visning på skærm og også gerne være visuelt tilpassede. Det skal også være muligt at tage højde for faglige niveauforskelle blandt eleverne. Det kan i LibGuide gøres ved at lave åbne spørgsmål, der kan løses forskelligt alt efter elevernes niveau. For at imødekomme disse ønsker, kunne en guideline til bidragyderne, og evt. links til allerede eksisterende e-læringsmateriale, om udvikling af elektronisk undervisningsmateriale, være et mål.

Med hensyn til kvaliteten af materialet i LibGuide er problemstillingen den samme som ved andre web 2.0 platforme, idet kvalitetssikringen også i LibGuide sker ved andre brugeres udvælgelse og brug af materialerne, dvs. hvis man sætter for høje krav til kvaliteten, er der måske for få, der byder ind, og hvis man sætter fællesnævneren for lav bliver platformen ikke brugt pga. dårlig kvalitet. Man kunne ved en søgning vise de mest brugte forløb først i søgeresultatet - lidt i stil med Googles resultatvisning og derved gå ud fra, at det flertallet bruger, må være det bedste materiale.

Der var fra undervisernes og bibliotekarernes side ønske om, at man skal kunne 'beskrive' det forløb, man lægger ind på en nem måde, f.eks. ved hjælp af afkrydsningsbokse med angivelse af fag, niveau og gymnasial retning, mens der skal være valgfrihed mht. emneord - evt. valgfri mulighed for at beskrive forløbet med en mindre tekst, omhandlende hvor lang tid tager forløbet, hvilke didaktiske overvejelser har der været og til sidst en evaluering på, hvordan det gik og hvilke ændringer kan man forslå. 
Det skal være muligt at kommunikere direkte i LibGuide underviser/elev og elev/elev.

Underviserne vil gerne have mere informationssøgning ind i undervisningen, og de er positive overfor at bruge LibGuide til opstart af et projekt. De vil godt bruge lang tid på at udarbejde et forløb, hvis det kan bruges til flere klasser, men det afhænger selvfølgelig også af, hvilket emne undervisningen skal dreje sig om.

Man er positive over for at LibGuide skal fungere som en platform for videndeling dvs. at den skal styrke integrationen mellem bibliotekar og underviser omkring udvikling af elevernes informationskompetence. Samarbejdet giver noget; både ved at få indblik i hinandens fagområder og selvfølgelig også ved den uformelle snak om projektet og ønsker til, hvad programmet skal kunne. Man bliver bedre til at formidle på tværs af fagene, og det kommer eleverne til gode i f.eks. vejledningen. Underviserne tror på, at den videndeling og dialog, der sker ved at lærere og bibliotekarer i samarbejde tilføjer forløb og genbruger det i andre sammenhænge og fag, er essensen i LibGuide og skal udbygges. Det er derfor meget vigtigt, at det er nemt at lægge materiale ind og ligeledes at genbruge andres materiale (Nielsen, 2009a; Nielsen, 2010; Andersen og Nielsen, 2009).

I forbindelse med et masterprojekt (Nielsen, 2009b) blev der udarbejdet en test af to klassers brug af LibGuide, hvor de to klasser blev stillet overfor samme test 2 gange med det formål at diskutere en mulig udvikling af deres informationskompetence hen over en fastsat tidsperiode. Testen viste at de to klasser forbedrede deres resultat af testen i forhold til de øvrige klasser. På baggrund af denne test blev nogle af lærerne interviewet. En htx teknologilærer udtaler om de implicerede parter: "De har også fået et fælles viden, en fælles platform. De får nogle fagudtryk, som de kan diskutere og som de kan bruge videre. Testen åbner op for noget og får nogle fagudtryk som så bliver gentaget i undervisningsforløbet senere. De ved mere hvor det bærer hen" (Nielsen, 2009b, s.35). Læreren antyder her, at eleverne, læreren og bibliotekaren fik et fælles sprog, termerne fra testen bliver nævnt senere i undervisningen. Til støtte herfor udtaler samme lærer også: "De snakker mere om informationssøgning end de har gjort før. De har snakket mere om informationssøgning ved at de skulle aflevere forslag til dig (bibliotekaren), om hvilke doku- menter de skulle vælge. Så på den måde arbejder de mere sammen om det" (Nielsen, 2009b, s.35).

\section{Blended learning}

I de tre fokusgruppeinterviews med faglærergrupper fra respektive gymnasieretninger var der stor enighed, at LibGuide skal sættes ind i en sammenhæng med god dialog, der skal altså ikke kun være tale om e-learning, men derimod 'blended learning'. Med blended learning menes der en undervisningsform, hvor ansigt-til-ansigt undervisning kombineres med computermedieret undervisning (Gynther, 2010). Platformen LibGuide skal således ikke stå alene.

Et af casene, der blev anvendt i forbindelse med den nævnte test af de to klasser, kan nævnes som eksempel på LibGuides inddragelse i et slags blended learning-undervisningsforløb (Nielsen, 2009a; Nielsen 2010). Casen beskriver hvordan et undervisningsmodul kan være bygget op: Underviseren holder et kort oplæg om det faglige emne, som eleverne skal i gang med, og bibliotekaren tager over i forhold til informationssøgning om emnet. Derefter får eleverne adgang til et forløb i LibGuide, som har direkte relation til deres projekt, hvor de f.eks. skal søge i forskellige databaser, og eleverne får som opgave, at de skal finde tre, for deres eget projekt, relevante dokumenter. Underviseren og bibliotekaren går imens rundt mellem eleverne og vejleder i forhold til at finde de tre relevante dokumenter.

En sådan opbygning af et undervisningsmodul blev i de ovenfor nævnte undervisningstilfælde anvendt flere gange. Lærerudtalelser antyder en tilfredshed med denne form. Det viser desuden, at LibGuide rummer muligheden for at indgå i en sådan undervisningsform. Nedenstående figur 3 viser et skærmbillede med et eksempel på, hvordan en del af et undervisningsforløb i Libguide (prototypen) kan se ud. Det viste eksempel i figur 3 er relateret til den ovenfor beskrevne case.

Der lægges som omtalt i casen vægt på samarbejde $\mathrm{i}$ informationsøgningsprocessen, f.eks. i diskussion af de tre søgte dokumenters validitet, hvor to elever først valgte dokumenterne, og to andre elever skulle evaluere deres udvælgelse af de tre "relevante dokumenter". Der foregår altså en dialog elev-til-elev om valg af dokumenter til brug i gruppens projekt. For at få eleverne endnu mere involveret vil der i vejledningen til den nye LibGuide blive lagt op til, at når 
eleverne to og to har fundet de tre dokumenter, skal de enten sende dem videre til resten af projektgruppen, eller til læreren/bibliotekaren, som kan give evaluering af det fundne. Elever kan screene andre elevers ressourcer og kan optræde som redaktører for hinanden. Det kan have den yderligere fordel, at det skærper elevernes opmærksomhed på at validere deres ressourcer, inden deres kammerater skal vurdere dem.

\section{Emnesøgning til teknologiprojekt om sundhed/HTX

\begin{tabular}{|c|}
\hline $\begin{array}{l}\text { Derefter går I videre til en søgning på "Alle biblioteker", som er en fæelles database } \\
\text { for alle biblioteker i DK. med adressen www.bibliotek.dk. De bøger eller artikler du } \\
\text { finder her, er det muligt at bestille hjem tIl din opgave, ganske gratis. }\end{array}$ \\
\hline $\begin{array}{l}\text { For at se om der er andet end bøger om emnet, vælger du at søge på artikler. } \\
\text { I har, efter de andre søgeresultater, fundet ud af, at I vil skrive om f.eks ..... i } \\
\text { forhold til sundhed. Derfor kombinerer du søgningen på sundhed med .....? (eller } \\
\text { en af de andre emner) } \\
\text { I bibliotek.dk kombinere I to ord, ved at sæette dem efter hinanden. "OG" er } \\
\text { underforstået. }\end{array}$ \\
\hline Alle biblioteker \\
\hline $\begin{array}{l}\text { Hvis ikke I får et godt resultat af jeres søgning, er det muligvis fordi I søger på de } \\
\text { forkerte ord. I kan finde synomymer af jeres søgeord eller I kan finde overordnede } \\
\text { ord. Andre ord for kost kan væere fødevarer, ernæring. Prøv at finde andre søgeord } \\
\text { og søg igen I "Alle biblioteker" Hvis I sætter "eller" imellem synonymer făr I } \\
\text { foreningsmængde dvs. fødevarer eller emæring eller kost. }\end{array}$ \\
\hline $\begin{array}{l}\text { FIND TRE ARTIKLER TIL JERES PROJEKT OG COPY OG PASTE TIL ET WORD } \\
\text { DOKUMENT og snak med resten af gruppen om, de mener I kan bruge artiklerne til } \\
\text { jeres projekt }\end{array}$ \\
\hline $\begin{array}{l}\text { Håber I har fundet noget til jeres projekt. Hvis ikke så prov at søge på jeres } \\
\text { emneord igen. Trunkerer jeres søgeord, det gøres I www.bibllotek.dk ved at sætte? } \\
\text { efter ordet. Trunkering betyder at søge pâ alle former af ordet. f.eks. Sundhed? } \\
\text { Kost? Motion? }\end{array}$ \\
\hline Forrige side \\
\hline
\end{tabular}

Figur 3. Skcermbillede med et eksempel på en del af et undervisningsforløb

Samlet set understøtter en sådan samarbejdsform informationssøgningens og informationsanvendelsens sociale karakter samt udviklingen af Libguide som den kommunikativt orienterede type af webvejledninger, der samtidig er kontekst-afhængig, jf. s. 8485. Det tilstræbes også i forhold til undervisere og bibliotekarer, hvor de i samarbejde udvikler undervisningsmateriale. Det er underviserens/bibliotekarens opgave at formulere den gode opgave, der kan fremme elevernes ansvarlighed og indbyrdes afhængighed med at få løst opgaven i fællesskab med så stor brugerinddragelse som muligt. Der er indbygget en mulighed for elevopsamling af gode søgesider, gode artikler og bøger om deres emner.

Denne vekselvirkning i sammensætningen af undervisningsmodulet som er beskrevet ovenfor er det, som Karsten Gynther kalder et undervisningsloop. Hermed menes en forløbsmodel, hvor undervisningen struktureres i loops hvor lærerens og bibliotekarens roller består af varierende elementer i form af formidlings-, evaluerings- og vejledningsloops (Gynther, 2010, s. 81ff.). En sådan forløbsmodel underbygger også arbejdet med at udvikle LibGuide til at være en type webvejledning, som ikke baserer sig på en procesorienteret men derimod en kommunikativ forståelse, jævnfør igen de fire typer af webvejledninger.

\section{Projektets fase 3}

\section{Forløb}

Projektets tredje fase har bestået i udarbejdelse af kravspecifikationen omkring den nye LibGuide og dermed projektmodningen med start februar $2011 \mathrm{og}$ afrapportering i september 2011 (www.deff.dk/aktuelt/artikel/projekt-libguide-fase-3-er-nu-afsluttet/). Den nye LibGuide skal anvendes til udvikling af elæringsforløb til undervisning i informationssøgning i et tæt og integreret samspil mellem bibliotekar, lærer og elev. Platformen udvikles fra en pædagogisk, biblioteksfaglig og teknologisk vinkel. Projektgruppen har i denne fase 3 inddraget resultater af fase 2 samt derudover bl.a. diskuteret forslag til forbedringer fra projektgruppen fra AAU.

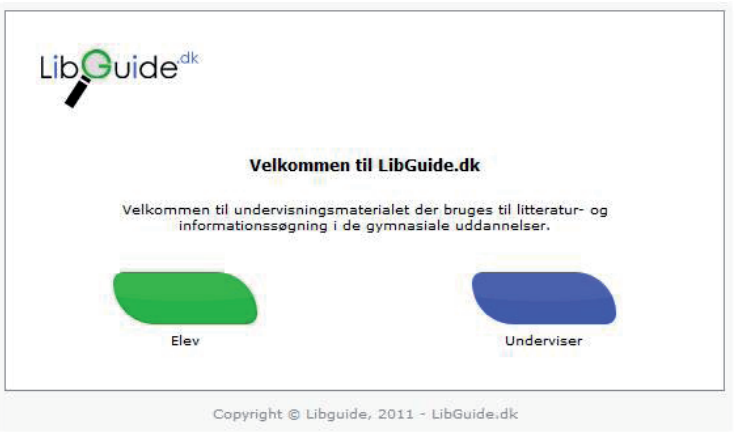

Figur 4. Skcermbillede fra Den Nye LibGuide (www. libguide.dk/new) (Ballegaard, 2011)

LibGuide er fortsat tænkt som et web 2.0 produkt, som alle undervisere og bibliotekarer i de gymnasiale uddannelser kan bidrage til, og hvor det er muligt for brugerne at kommunikere direkte i platformen. De enkelte bidrag skal kunne genbruges og videreudvikles af andre, og skal derfor struktureres ved hjælp af emneord, gymnasial retning og niveauet for informationskompetence, så de enkelte forløb bliver søgbare. På denne måde skal LibGuide gerne styrke videndeling mellem uddannelsesinstitutionerne og mellem lærere og bibliotekarer på de gymnasiale uddannelser. 
Igen inddrages erfaringer fra andre undersøgelser. Ryberg (2009) behandler resultater fra en britisk undersøgelse, hvor han skriver at "En større undersøgelse af brugen af web $2.0 \mathrm{i}$ de britiske skoler (....) konkluderer f.eks. at brugen af web 2.0 kan højne engagement og deltagelse. Samt, at sociale netværksteknologier kan fremme online diskussioner, og dermed udbygge læringen. Dertil, at følelsen af ejerskab over materiale publiceret/delt online gør eleverne mere opmærksomme på at forbedre kvaliteten af deres produktioner" (Ryberg, 2009, s. 13). Resultaterne fra den britiske undersøgelse vil blive søgt indarbejdet i den nye LibGuide for yderligere at understøtte at eleverne går fra at være modtagere af undervisning til at være aktive deltagere i læreprocessen.

Dette forsøges ved f.eks. at understøtte dialog-stadiet i LibGuide via en chatfunktion. Dialogen skal også fremmes gennem undervisningssituationer som før beskrevet, hvor eleverne sidder to og to for at gennemgå et forløb eller en test i LibGuide, hvortil det er meningen at eleverne skal diskutere med hinanden og underviseren. Som en opsummering på forløbet er det tiltænkt, at der skal reflekteres og diskuteres i plenum om søgeresultaterne.

I fase 3 har vi som nævnt været så heldige at få involveret fire studerende fra AAU. Her fik vi igen fornøjelsen af, at se hvad dialog og samarbejde kan føre til, og det blev en øjenåbner for, hvad der tænkes på, når vi snakker om undervisning og informationskompetence. De studerende fra Aalborg Universitet relaterede til deres egen gymnasietid og tænkte på undervisning, som den biblioteksintro de fik til det nærmeste folkebibliotek og havde svært ved at se bibliotekaren på lige fod med underviserne på de gymnasiale uddannelser - som en del af det lokale uddannelsesmiljø og en del af gymnasieelevernes hverdag. Den opfattelse håber vi, at LibGuide kan være med til at ændre på.

\section{Personificering}

I kravspecifikationen til den nye LibGuide er de mange observationer og forslag til forbedringer forsøgt indopereret. Undervisningsforløbene i fase 2 viste at rigtig mange elever benyttede muligheden for at ændre baggrunden inde på platformen, og der- med personificere siden, men da det ikke var muligt at gemme denne ændring gav det ikke rigtig mening at gøre det. I forbindelse med et andet projekt eller eksamen kunne det også være en fordel at kunne gemme et forløb og dermed gøre det muligt at vende tilbage til dette. Det skal derfor være muligt for brugeren at have sin egen LibGuideprofil. I den forbindelse er der blevet arbejdet på at give adgang til LibGuide igennem brugerens Facebookprofil.

For yderligere at personificere og involvere elevernes LibGuideprofil, arbejdes der på at få indarbejdet såkaldt gamification (Zichermann, 2011) i LibGuide, således at man kan samle på små digitale badges ${ }^{3}$, der vises i ens brugerprofil, og som kan ses af andre brugere. Man får badges alt afhængig af, hvor mange forløb man har gennemført, og hvor godt man har klaret sig i de forskellige tests. Med badges håber vi bl.a. at få det konkurrenceelement ind, som flere af eleverne i projektets fase 2 viste stor interesse for $\mathrm{i}$ forbindelse med gennemførelse af testene, der i den gamle LibGuide havde en pointtæller. Dette pointsystem skal også bevares i testene og gerne med en highscore.

Personifisering af LibGuide kan være med til at motivere eleverne til at anvende LibGuide. De får deres egen profil, som de kender fra andre sociale medier under betegnelsen "Min profil". Det er vigtigt, at eleven har mulighed for at bestemme præcis, hvordan deres profil skal se ud, hvor de forskellige elementer skal stå i forhold til hinanden. Det skal være muligt at ændre med simple drag-and-drop teknikker. Ydermere får de en liste over de badges, som de har optjent ved at bruge platformen (se figur 5).

LibGuide skal som sagt gerne være det som Dalsgaard (2011) har kaldt en åben ressource til forskel fra andre kendte webvejledninger i informationskompetence som f.eks. UB-testen eller SWIM. Det skal være et redskab for mediering, hvad enten det er elevernes udveksling af materiale eller lærernes undervisningsmateriale, der skal distribueres til eleverne. Brugerne skal selv være med til at definere indholdet og aktiviteterne, som indholdet skal bruges til. 


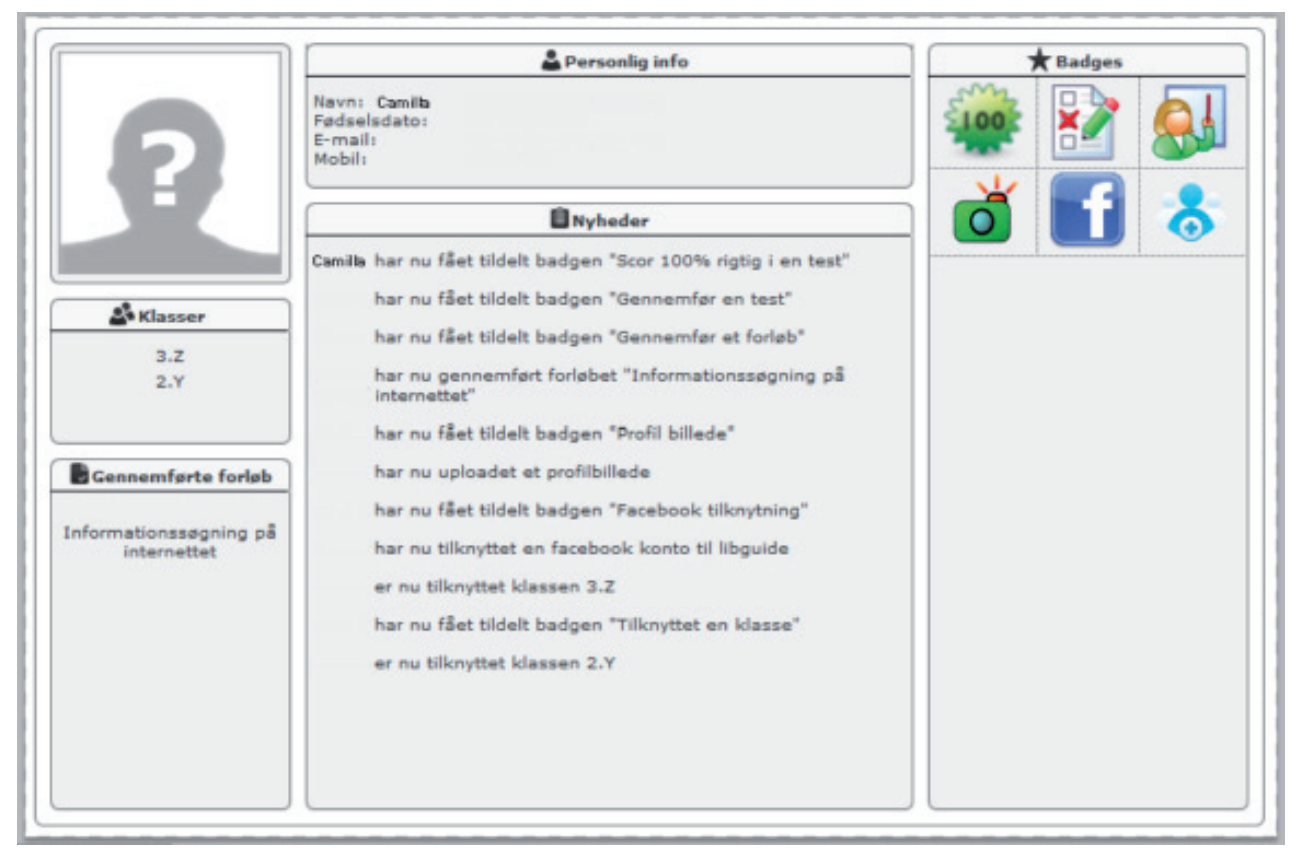

Figur 5. Skcermbilledet skitserer elevens profil. Billedet er en del af designet af "Den Nye LibGuide" (Ballegaard, 2011, s.10)

\section{Konklusion}

Web 2.0 er en tidssvarende og relevant indgangsvinkel til at udvikle et e-læringsværktøj. Det stiller imidlertid store krav til, at værktøjet samtidig er enkelt og effektivt at bruge for elever så vel som lærere og bibliotekarer.

Om platformen har potentiale til at blive udbredt til hele gymnasieverdenen, er endnu for tidligt at sige. Det er betinget af det videre arbejde i en fase 4, færdigudviklingen af LibGuide. Der er ingen tvivl om, at projektet vil vokse meget, hvis videreudviklingen sker i samme omfang som i de to første faser. I de tre faser har LibGuide udviklet sig fra i fase 1 at være et værktøj med et tilbud om nogle søge- og opbevaringsfaciliteter, videre i fase 2 til at være et værktøj som skal ses som en del af blended learning, og endelig i fase 3 til at besidde direkte dialogmuligheder samt en personificeringsdimension, hvor eleverne får deres egen profil, platformen får et bedre design, bedre redigeringsmuligheder og mulighed for længere forløb.

De to teoretiske inspirationskilder, nemlig dels ideen om et webbaseret værktøj i informationskompetence der er kommunikationsorienteret, og dels konstruk- tionen omkring de 'digital natives', indgår stadigvæk som en del af den vision, der bærer projektet og skubber det videre fremad. Igennem de forskellige faser har det været dialogen og samarbejdet med de forskellige brugergrupper og sparringspartnere, som har været vigtigere frem for straks at kunne opvise et færdigt produkt. En central erkendelse er at det indirekte kan være en ulempe at prioritere en sådan fremadskridende udviklingsproces - det er mere synligt at vise et flot produkt end en flot proces!

En konklusion på projektets fase 2 var, at der synes at være et behov for en e-læringsplatform af den beskrevne karakter. I fase 3's kravspecifikationer er der fremkommet en masse spændende forslag, som uden tvivl kan være med til at højne kvaliteten af den nye LibGuide og efterstræbe indfrielsen af visionen. På http://www.libguide.dk/new kan et foreløbigt design ses. Fase 3 er afsluttet september 2011.

De to teoretiske inspirationskilder har betydet, at projektet med LibGuide fra starten har haft et højt ambitionsniveau. Sådan et projekt vil aldrig have et helt enkelt forløb. Der er mange dimensioner, der ønskes indarbejdet i værktøjet for, at det kan tilfredsstille den opstillede vision. Et fleksibelt værktøj, en såkaldt 'åben ressource', som er tilpasset alle de for- 
skellige typer af deltagere og deres behov for videndeling og kommunikation, vil i sin udviklingsproces skulle afprøve mange veje og eventuelle vildveje før det er færdigudviklet. Projektgruppens mål er at udvikle den nye prototype og igen få den afprøvet og herved igen indsamle erfaringer. Der er ikke tale om en liniær udviklingsproces, hvor et enkelt mål er konkretiseret indledningsvis, og hvor man på forhånd kender midlerne for at nå frem til dette. Der er derimod tale om et projekt, hvor der fra starten er en vision baseret på teoretiske begreber, og hvor konkretiseringen af en række delmål gennem et eksplorativt forløb efterhånden træder tydeligere frem. Nye erfaringer vil give nye delmål som led i at virkeliggøre den overordnede vision.

\section{Noter}

1. Swim: http://www.aub.aau.dk/hjaelp-inspiration/ swim/

2. UB-testen: http://www.ubtesten.dk/

3. http://www.4squarebadges.com/

\section{Referencer}

American Library Association (ALA) (1989). Lokaliseret d. 23. 08. 2011 på http://www.ala.org/ala/ mgrps/divs/acrl/standards/informationliteracycompetency.cfm\#ildef

Aggerbeck, M (2007). En reformulering af bibliotekets rum og funktioni fremtidens uddannelsessystemer. I: M. Rosenstand et al.(red.) Fra information til loering. Bibliotek og uddannelse $i$ vidensamfundet s.63-74. Kbh.: DEFF.

Andersen, EM \& Nielsen, S (2009). Lib-guide - et redskab til samarbejde. Modulopgave i informationskompetence og læring. Kbh.: Danmarks Biblioteksskole.

Ballegaard, A et. al. (2011). LibGuide.dk. Bachelorprojekt i Informationsteknologi \& Informationsvidenskab). Aalborg: AAU.

Bekendtgørelse af lov om uddannelsen til studentereksamen (stx) (gymnasieloven). Lokaliseret d. 12.09.2011 på https://www.retsinformation.dk/ Forms/r0710.aspx?id=132542.
Bennett, S, Maton, K \& Kervin, L (2008). The 'digital natives' debate: A critical review of the evidence. I: British Journal of Educational Technology, Vol. 39, $n$ r. 5, p. 775-786.

Birch Andreasen, L et.al. (2008). Digitale medier og didaktiske design: brug, erfaringer og forskning. Kbh.: Danmarks Pædagogiske Universitet.

Dalsgaard, C (2010). Vidensmedier på nettet. Fabulær: faggruppen for biblioteksunderstøttet læring. Lokaliseret d. 12.09.2011 på http://pure.au.dk/portal/ files/34744774/FaBuL_r_VidensmedierPaaNettet.pdf

Dalsgaard, C (2011). Vidensmediers liv på nettet. I: H.J. Nielsen, H. Høyrup, og H. Dam Christensen. (red.) Nye Vidensmedier. Kultur, Laring, Kommunikation. Frederiksberg C: Samfundslitteratur. 171189.

Gynther, K (red.) (2010). Didaktik 2.0: lceremiddelkultur mellem tradition og innovation. Kbh.: Akademisk forlag.

Hedman, J, \& Lundh, A (red) (2009). Informationskompetenser: om lärande i informationspraktiker och informationssökning i lärandepraktiker. Stockholm: Carlssons.

Holm, C et al. (2010). Informationskompetence $i$ Gymnasiet - Et debatoplaeg. Århus: Danmarks Pædagogiske Universitet, Århus Universitet.

Limberg, L, Alexandersson, M, \& Lantz-Andersson. (2008) What Matters? shaping Meaningful Learning through Teaching Information Literacy. Libri, vol. $58,82-91$.

Joint Information Systems Committee (JISC) (2010). Web 2.0. Sidst opdateret 20.09.10. Lokaliseret den 12.09.2011 på http://www.jisc.ac.uk/whatwedo/topics/web2

Just, M \& Elbeshausen, H (2008). Jeg drikker aldrig en kop kaffe på lærerværelset. Gymnasiebibliotekarerne og det refleksive læringsmiljø: en figurationssociologisk analyse. Dansk Biblioteksforskning, nr.1, 21-32.

Nielsen, Susanne (2009a). Afrapportering for e-læringsprogrammet Lib-guide. Lokalise- 
ret d. 22.09.2011 på: http://nyeinstitutioner.deff. wikispaces.net/file/view/Afrapportering+-+LibGuide+I.pdf

Nielsen, S (2009b). Integration af informationskompetencer i projektforløb på gymnasiale uddannelser. Afgangsprojekt til Master i Biblioteks- og Informationsvidenskab. Kbh. Danmarks Biblioteksskole. Lokaliseret d. 01.05.2010 på http://pure.iva.dk/ files/30775001/Integration_af_informationskompetence1_2_.pdf

Nielsen, S (2009c). Projekt Lib-guide - et samarbejde. DF Revy, nr. 4, maj 2009. Lokaliseret d. 01.05.2010 på http://rauli.cbs.dk/index.php/revy/article/viewFile/2530/2531

Nielsen, S (2010). Afrapportering af Lib-guide fase 2. Kbh.: DEFF. Lokaliseret d. 30.09.2011 på http:// www.deff.dk/aktuelt/artikel/lib-guide-fase-2-er-naaet-i-hus

O'Reilly, T (2005). What is Web 2.0: Design Patterns and Business Models for the Next Generation of Software. Lokaliseret d. 15.08.2011 på http:// mpra.ub.uni-muenchen.de/4578/1/MPRA_paper_4578.pdf
Palfrey, J \& Gasser, U (2008). Born digital. Understanding the first generation of digital natives. New York: Basic Books.

Prensky, M (2001). Digital Natives, Digital Immigrants. I: On the Horizon. MCB University Press, Vol. 9, No. 5, October 2001. Lokaliseret d. 09.09.2011 på http://www.marcprensky.com/writing/ prensky $\% 20-\% 20$ digital $\% 20$ natives, $\% 20$ digital $\% 20$ immigrants\%20-\%20part1.pdf

Ryberg, T (2009). Digitale indfødte - Hvis teknologien er i blodet, hvad så med skolen. Ungdomsforskning: unge og teknologi, Nr. 3-4, 9-18.

Sundin, O. (2006). Informationskompetence, ikt og bibliotekarers professionelle ekspertise. I: T. Schreiber, Bibliotekarerne: en profession i et felt af viden, kommunikation og teknologi. Frederiksberg C: Forlaget Samfundsvidenskab, 77-96.

Zichermann, Gabe (2011). Spil dig gennem hverdagen. (Harddisken, DR. P1 23. februar 2011 kl. 13:03 på P1 Lokaliseret d.01.05.2011 på: http://www.dr.dk/ P1/harddisken/Udsendelser/2011/02/23141653.htm 